${ }^{1}$ Katedra i Klinika Chorób Wewnętrznych, Diabetologii i Nefrologii Śląskiego Uniwersytetu Medycznego w Zabrzu

${ }^{2}$ Katedra i Klinika Chorób Metabolicznych Collegium Medicum Uniwersytetu Jagiellońskiego w Krakowie

${ }^{3}$ Klinika Chorób Wewnętrznych i Diabetologii Uniwersytetu Medycznego w Łodzi

${ }^{4}$ Oddział Kliniczny Chorób Wewnętrznych Diabetologii i Schorzeń Kardiometabolicznych Śląskiego Uniwersytetu Medycznego w Zabrzu

${ }^{5}$ Klinika Diabetologii i Chorób Wewnętrznych Pomorskiego Uniwersytetu Medycznego w Szczecinie

${ }^{6}$ Katedra i Klinika Chorób Wewnętrznych i Diabetologii Uniwersytetu Medycznego im. Karola Marcinkowskiego w Poznaniu

${ }^{7}$ Klinika Endokrynologii, Diabetologii i Chorób Wewnętrznych Uniwersytetu Medycznego w Białymstoku

\title{
Badanie ADVANCE-ON na tle innych badań follow-up - komentarz do wyników
}

\author{
ADVANCE-ON trial against other follow-up studies \\ - a comment on the results
}

Mimo ogromnego postępu medycyny, wprowadzenia do terapii insuliny i kolejnych grup leków obniżających stężenie glukozy we krwi, a także doskonalenia metod jej monitorowania rozwój późnych powikłań naczyniowych pozostaje najistotniejszym problemem współczesnej diabetologii, w sposób zasadniczy wpływając na skrócenie przewidywanego okresu życia oraz pogorszenie jego jakości.

Dostępne badania wskazują na istnienie ścisłego związku między stopniem i czasem trwania podwyższonego stężenia glukozy we krwi a ryzykiem rozwoju przewlekłych powikłań naczyniowych cukrzycy. Dążenie do normalizacji stężenia glukozy we krwi jest zatem, obok terapii współistniejących zaburzeń gospodarki tłuszczowej, masy ciała i podwyższonych wartości ciśnienia tętniczego, zgodnie z zaleceniem wielokierunkowego, całościowego leczenia cukrzycy typu 2, kluczowym sposobem zapobiegania lub zwolnienia tempa progresji powikłań naczyniowych. Udowodniły

Adres do korespondencji:

prof. dr hab. med. Janusz Gumprecht

Katedra i Klinika Chorób Wewnętrznych,

Diabetologii i Nefrologii

Śląski Uniwersytet Medyczny

ul. 3 Maja 13/15, 41-800 Zabrze

Tel.: +48 (32) 2712511

Faks: +48 (32) 2714617

Diabetologia Kliniczna 2015, tom 4, 1, 29-33

DOI: $10.5603 /$ DK.2015.0005

Copyright (C) 2015 Via Medica

Nadesłano: 23.04.2015

Przyjęto do druku: 23.04.2015 to wyniki dużych badań klinicznych, takie jak Diabetes Control and Complications Trial (DCCT) dotyczące cukrzycy typu 1 czy United Kingdom Prospective Diabetes Study (UKPDS) dotyczące cukrzycy typu 2. Na podstawie szczegółowej analizy rezultatów tych badań oraz wyników badań STENO i STENO-2, a także dużych badań klinicznych z 2008 roku - Action to Control Cardiovascular Risk in Diabetes (ACCORD), Action in Diabetes and Vascular Disease-Preterax and Diamicron Modified Release Controlled Evaluation (ADVANCE) i Veterans Affairs Diabetes Trial (VADT) można stwierdzić, że dążenie do optymalnego wyrównania glikemii nie przynosi korzyści wszystkim chorym na cukrzycę typu 2. Największa efektywność i bezpieczeństwo takiej terapii dotyczy pacjentów ze świeżo rozpoznaną cukrzycą lub chorujących krótko, dość dobrze wyrównanych metabolicznie, u których dotychczas nie rozwinęły się powikłania makroangiopatyczne.

Badanie ADVANCE prowadzono w latach 2001-2008 w 215 ośrodkach, które włączyły do próby ponad 11 tys. chorych na cukrzycę typu 2 z obecnymi czynnikami ryzyka chorób sercowo-naczyniowych, obejmujących bardzo różne populacje pacjentów z 20 krajów świata, zlokalizowanych na różnych kontynentach. Średni wiek chorych w chwili rozpoczęcia badania wynosił 66 lat, średni czas trwania cukrzycy - 8 lat, średnie wartości hemoglobiny glikowanej $\left(\mathrm{HbA}_{1 \mathrm{c}}\right)-7,5 \%$, a wartości ciśnienia tętniczego - 145/81 mm Hg.

Chorych randomizowano albo do leczenia przeciwcukrzycowego typowego dla danego ośrodka, 
albo do grupy interwencyjnej w zakresie glikemii, w której dodatkowo stosowano gliklazyd MR w dawce 60-120 mg/dobę, przyjmując jako cel terapeutyczny wartość $\mathrm{HbA}_{1 c}<6,5 \%$. Każda z badanych grup objęła około 5,5 tys. osób (randomizacja 1:1). Drugi sposób interwencji, przeprowadzony niezależnie od pierwszego, obejmował łączne podawanie perindorpilu w dawce $4 \mathrm{mg}$ i indapamidu w dawce 1,5 mg, w postaci preparatu złożonego, podawanego dodatkowo, niezależnie od rutynowo stosowanej terapii hipotensyjnej, przy czym wartości docelowe ciśnienia tętniczego nie zostały zdefiniowane. Każda z grup objęła również około 5,5 tys. chorych, ponieważ randomizację prowadzono w stosunku 1:1. Czas obserwacji pacjentów w ramieniu hipoglikemizującym wynosił około 5 lat, a w ramieniu hipotensyjnym około 4,4 roku. Obserwowane pierwszorzędowe punkty końcowe badania ADVANCE objęły powikłania o typie makroangiopatii i mikroangiopatii analizowane łącznie lub oddzielnie. Powikłania makroangiopatyczne zdefiniowano jako zgon z przyczyn sercowo-naczyniowych, zawał serca lub udar mózgu niezakończone zgonem. Powikłania o typie mikroangiopatii związane z funkcją nerek objęły pojawienie się lub pogorszenie nefropatii cukrzycowej oceniane na podstawie wystąpienia makroalbuminurii, podwojenia stężenia kreatyniny $w$ surowicy do wartości $\geq 200 \mu \mathrm{mol} / \mathrm{l}$, włączenia dializoterapii lub wystąpienia zgonu z przyczyn nerkowych. Okulistyczne powikłania mikroangiopatyczne definowano także jako rozwój lub pogorszenie retinopatii diagnozowane na podstawie wystąpienia retinopatii proliferacyjnej, obrzęku plamki żółtej, zabiegu laseroterapii lub wystąpienia utraty wzroku. Punkty drugorzędowe objęły: zgony z wszystkich przyczyn, zgony sercowo-naczyniowe, duże incydenty wieńcowe (zgony sercowe, zawały serca nie zakończone zgonem), wszelkie incydenty wieńcowe (ostre zespoły wieńcowe, zawały nieme, rewaskularyzacje naczyń wieńcowych, hospitalizacje z powodu niestabilnej choroby wieńcowej), duże incydenty naczyniowo-mózgowe (zgony z powodu choroby naczyniowej mózgu, udary niezakończone zgonem) i inne incydenty naczyniowo-mózgowe (w tym przemijające niedokrwienie mózgu i krwawienia podpajęczynówkowe). Do punktów drugorzędowych zaliczono także powikłania o typie nefropatii i retinopatii, definiowane jak powyżej, ale wówczas, gdy były one analizowane oddzielnie. Jako drugorzędowe punkty oceny ujęto ponadto niewydolność serca (hospitalizacje, pogorszenie stanu i zgony z tego powodu), choroby naczyń obwodowych, pojawienie się lub pogorzenie neuropatii, demencję, hospitalizacje.

W grupie interwencji w zakresie leczenia hipoglikemizującego obserwowano przez cały czas istotnie mniejsze wartości $\mathrm{HbA}_{1 c^{\prime}}$ które na zakończenie badania wynosiły średnio $6,5 \%$ vs. 7,3\% ( $p<0,001)$. Spośród badań z 2008 roku jedynie w ADVANCE intensywna terapia glikemii oparta na gliklazydzie MR skutkowała, w porównaniu z leczeniem standardowym, 10-procentowym zmniejszeniem częstości występowania wszystkich powikłań naczyniowych cukrzycy. Redukcja ta była przede wszystkim konsekwencją korzystnego wpływu intensywnego leczenia na ryzyko nefropatii, które zostało obniżone aż o 21\%. Należy też podkreślić, że intensywne leczenie wiązało się z obniżeniem o $65 \%$ częstości występowania terminalnej niewydolności nerek wymagającej terapii nerkozastępczej. Ponadto leczenie intensywne wiązało się z obniżeniem o 30\% częstości występowania białkomoczu, będącego uznanym markerem ryzyka sercowo-naczyniowego. Zaobserwowano również 12-procentowy trend w kierunku obniżenia liczby zgonów z przyczyn sercowo-naczyniowych w grupie leczonej intensywnie. Trzeba jednak zaznaczyć, że nie stwierdzono znamiennego wpływu zintensyfikowanego leczenia na częstość występowania zawałów serca, udarów mózgu, śmiertelności sercowo-naczyniowej i całkowitej.

W grupie interwencji w zakresie leczenia hipotensyjnego (perindopril/indapamid) przez cały okres trwania badania obserwowano istotnie mniejsze wartości ciśnienia skurczowego (śr. o 6,5 mm Hg; $\mathrm{p}<0,0001$ ) i rozkurczowego (śr. o 2,2 mm Hg; $\mathrm{p}<0,0001$ ). W grupie otrzymującej dodatkowy lek hipotensyjny stwierdzono zmniejszenie ryzyka względnego powikłań makro- i mikronaczyniowych ocenianych łącznie o 9\%, wszystkich zgonów o 14\%, zgonów sercowo-naczyniowych o 18\% oraz redukcję ryzyka względnego rozwoju/pogorszenia nefropatii o $21 \%$. Nie zanotowano obniżenia ryzyka powikłań o typie makroangiopatii i mikroangiopatii rozpatrywanych oddzielnie ani zmniejszenia ryzyka rozwoju/pogorszenia retinopatii.

Wyniki badania Diabetes Control and Complication Trial (DCCT) i będącej jego przedłużeniem części obserwacyjnej - Epidemiology of Diabetes Intervention and Complications (EDIC) - wykazały istotne znaczenie intensywnej kontroli glikemii w zmniejszeniu częstości powikłań naczyniowych w cukrzycy typu 1 oraz dały podstawy do zaproponowania terminu określanego mianem pamięci metabolicznej. Pod pojęciem tym rozumie się korzystne zmiany w odniesieniu do powikłań naczyniowych cukrzycy uzyskane w następstwie jej intensywnej terapii, które utrzymują się mimo powrotu do zwykłego, rutynowego, a często także gorszego wyrównania metabolicznego choroby. Zjawisko to w badaniu DCCT/EDIC obserwowano nie tylko w odniesieniu do retinopatii i nefropatii, lecz także (EDIC) w stosunku do powikłań makronaczyniowych, gdzie 
ryzyko sercowo-naczyniowe było mniejsze w grupie początkowo, w fazie badania randomizowanego, leczonej intensywnie. Podobnie dane pochodzące z 10-letniej obserwacji chorych na cukrzycę typu 2, którzy uprzednio uczestniczyli w randomizowanej części badania UKPDS, a po okresie leczenia intensywnego lub konwencjonalnego wrócili do standardowej terapii, wskazują na utrzymywanie się korzystnych efektów naczyniowych wśród osób leczonych intensywnie od początku rozpoznania choroby.

Takich zależności nie zanotowano natomiast w kontynuacji badania ADVANCE, które nie wykazało korzyści z uprzedniej intensywnej kontroli glikemii, poprzedzającej obserwację odległą, w liczącej 8494 chorych populacji badania ADVANCE-ON.

ADVANCE-ON było badaniem obserwacyjnym, które podjęto w 2010 roku, czyli 2 lata po zakończeniu próby ADVANCE. Do badania zaproszono te same ośrodki i tych samych chorych, którzy uczestniczyli w badaniu randomizowanym, przy czym przez okres 2 lat między badaniami chorzy byli leczeni przez lekarzy prowadzących w sposób dowolny, zgodny z lokalnymi zwyczajami i wytycznymi. Łącznie do badania włączono około 8,5 tys. osób. Z pierwotnych grup interwencji lub obserwacji w zakresie glikemii do badania ADVANCE-ON włączono grupy, z których każda liczyła ponad 4,2 tys. pacjentów. Z grup interwencji/obserwacji nadciśnieniowej także włączono dwie grupy liczące ponad 4,2 tys. chorych. Kohorta uczestników badania ADVANCE-ON była w pełni reprezentatywna dla pierwotnej populacji badania ADVANCE, ponieważ charakterystyka wyjściowa pacjentów w pełni pokrywała się z charakterystyką chorych włączanych i randomizowanych do badania ADVANCE, zarówno w odniesieniu do wieku, wyjściowego wyrównania cukrzycy, wartości ciśnienia tętniczego, obecności schorzeń sercowo-naczyniowych czy mikroangiopatii. W latach 2010-2013/2014 chorzy zostali objęci 3-letnią obserwacją, którą ukończyło 5,1 tys. z nich. Wizyty odbywały się każdego roku.

Oceniane punkty pierwszorzędowe $\mathrm{w}$ badaniu ADVANCE-ON objęły zgony ze wszystkich przyczyn i powikłania o typie makroangiopatii definiowane jak w badaniu ADVANCE (łącznie: zgon z przyczyn sercowo-naczyniowych, zawał serca lub udar mózgu niezakończony zgonem). Punkty drugorzędowe objęły zgon z przyczyn sercowo-naczyniowych, zawał serca lub udar mózgu (zakończone lub niezakończone zgonem) i duże powikłania mikroangiopatyczne obejmujące łącznie nefropatię i retinopatię. Definicja mikroangiopatii była inna niż w badaniu ADVANCE. Dla nefropatii była to dializoterapia lub zgon z przyczyn nerkowych, dla retinopatii - laseroterapia lub utrata wzroku.
Dane w badaniu ADVANCE-ON zbierano głównie na podstawie informacji ankietowych uzyskanych telefoniczne od lekarzy, od chorych lub ich rodzin, rzadziej w czasie wizyt domowych lub w trakcie osobistych wizyt pacjentów u lekarza. Wywiad obejmował także leczenie stosowane w chwili włączenia do badania ADVANCE-ON. U około 2 tys. chorych w czasie pierwszej wizyty badania ADVANCE-ON wykonano/zebrano dane obejmujące wartości $\mathrm{HbA}_{1 c^{\prime}}$ ciśnienia tętniczego, stężenia kreatyniny w surowicy oraz stężenia albuminy i kreatyniny w moczu.

Obserwacja chorych w badaniu ADVANCE-ON wykazała, że grupy nie różniły się pod względem terapii stosowanej po zakończeniu badania randomizowanego ADVANCE i parametrów, takich jak $\mathrm{HbA}_{1 c}$ i ciśnienie tętnicze.

W grupie chorych otrzymujących wcześniej perindopril/indapamid stwierdzono różnicę w zakresie pierwszorzędowych punktów końcowych - mniejsze ryzyko zgonu z wszystkich przyczyn (HR 0,91; 95\% $\mathrm{Cl} 0,84-0,99 ; \mathrm{p}=0,03$ ) i różnicę dotyczącą jednego z punktów drugorzędowych - mniejsze ryzyko zgonu z przyczyn sercowo-naczyniowych (HR 0,88; 95\% Cl 0,77-0,99; $p=0,04)$.

Wyniki badania ADVANCE-ON potwierdzają korzyści aktywnego leczenia hipotensyjnego u chorych na cukrzycę typu 2. Osiągnięty w pierwszych 4 latach sukces terapeutyczny stwarza szansę na dłuższe przeżycie. Stało się tak niezależnie od wyjściowego ciśnienia tętniczego krwi oraz od zbliżonych jego wartości stwierdzanych w obu grupach w części obserwacyjnej badania (137/74 mm Hg i 138/75 mm Hg). Pamiętając, że uczestnicy ADVANCE-ON stanowili reprezentatywną populację dla badania ADVANCE, trzeba jednak dodać, że po zakończeniu prospektywnego badania randomizowanego osoby $z$ aktywnego ramienia hipotensyjnego zaprzestały w zdecydowanej większości (> 90\%) stosować złożony preparat perindopril-indapamid. Ponadto niektórzy zaprzestali przyjmowania jakichkolwiek leków hipotensyjnych. To wszystko tylko umacnia wnioski płynące $z$ aktywnego ramienia hipotensyjnego w części interwencyjnej badania. Metodologia badania ADVANCE-ON pozwala ocenić odległe następstwa po ponad 4-letniej interwencji, ale nie daje odpowiedzi na pytanie dotyczące skali korzyści, których można by się spodziewać po wydłużeniu czasu przyjmowania przez chorych na cukrzycę typu 2 złożonego preparatu perindopril-indapamid.

Rezultaty badania ADVANCE-ON stanowią uzupełnienie i wzmocnienie analiz odległych wyników z innych badań, czyli części obserwacyjnej Heart Outcomes Prevention Evaluation-The Ongoing Outcomes (HOPETOO) czy Systolic Hypertension in Europe (Syst-Eur 
trial). W pierwszym z wymienionych, w populacji osób z chorobami sercowo-naczyniowymi i/lub cukrzycą, korzyści w zakresie zmniejszenia ryzyka zdarzeń sercowo-naczyniowych i zgonu utrzymywały się po kilku latach, pomimo zrównania średnich wartości ciśnienia tętniczego w obu grupach obserwowanych uprzednio w części randomizacyjnej badania. Podobne, przedłużone w czasie korzyści z interwencji hipotensyjnej odnotowano także w drugim z wymienionych badań, przeprowadzonym w populacji osób w wieku podeszłym z izolowanym skurczowym nadciśnieniem tętniczym. Odległe korzyści wynikające z aktywnej terapii nadciśnienia tętniczego nie utrzymywały się po 10 latach obserwacji u chorych na cukrzycę typu 2 uczestniczących w badaniu UKPDS. Jednak uczestnicy obu badań, UKPDS i ADVANCE, różnili się pod wieloma względami, między innymi czasem trwania cukrzycy, stopniem kontroli glikemii, ryzykiem sercowo-naczyniowym oraz stosowanymi lekami, zarówno przeciwhiperglikemicznymi, hipotensyjnymi, jak i hipolipemizującymi. Uczestnicy badania ADVANCE byli starsi, z wieloletnią cukrzycą typu 2, a co trzeci z nich przebył incydent sercowo-naczyniowy. Należy pamiętać, że kontrola glikemii nie była najgorsza, gdyż u większości wartość $\mathrm{HbA}_{1 c}$ nie przekraczała $8 \%$. Wyniki odległe badania ADVANCE-ON powinny być postrzegane przez pryzmat takich właśnie pacjentów.

Intensywna kontrola glikemii w obserwacji długoterminowej badania ADVANCE-ON nie wpływała zarówno na śmiertelność całkowitą, jak i sercowo-naczyniową [HR odpowiednio 1,00 (95\% Cl 0,92-1,08) i 1,00 (95\% Cl 0,92-1,08)].

Nie stwierdzono także różnic w zakresie wpływu intensywnej kontroli glikemii w obserwacji przedłużonej badania ADVANCE-ON na ryzyko występowania dużych epizodów makronaczyniowych (złożony, pierwszorzędowy punkt końcowy definiowany podobnie jak w części randomizowanej badania ADVANCE jako niezakończony zgonem zawał serca, niezakończony zgonem udar mózgu lub zgon sercowo-naczyniowy; HR 1,00; 95\% Cl 0,92-1,08) i mikronaczyniowych (złożony, drugorzędowy punkt końcowy definiowany jako konieczność terapii nerkozastępczej, zgon z przyczyn nerkowych, konieczność wykonania fotokoagulacji siatkówki lub utrata widzenia w którymkolwiek oku; HR 0,92; 95\% Cl 0,80-1,05).

Korzyści naczyniowe w badaniu ADVANCE-ON wynikały głównie z, utrzymanego w obserwacji odległej, korzystnego wpływu intensywnej terapii hipoglikemizującej opartej na gliklazydzie MR na częstość wystąpienia i progresji nefropatii cukrzycowej wyrażonej zmniejszeniem ryzyka wystąpienia schyłkowej niewydolności nerek (skumulowana redukcja ryzyka w obserwacji całkowitej obejmującej 9,9 roku - 46\%; HR 0,54; $95 \%$ Cl 0,34-0,85; $\mathrm{p}=0,007)$. Powyższa obserwacja ma także znaczenie praktyczne, wskazuje bowiem jednoznacznie, że u pacjentów z długo trwającą cukrzycą typu 2 intensywna kontrola glikemii jest kluczowa dla prewencji ważnych kliniczne nerkowych punktów końcowych.

Jako przyczynę obserwowanych różnic w długoterminowych korzyściach wynikających z uprzedniej intensywnej terapii hipoglikemizującej stwierdzonych w badaniu ADVANCE-ON w odniesieniu do wyników badań DCCT/EDIC czy UKPDS sugerowany jest starszy wiek analizowanej populacji w odniesieniu do pierwszego z wymienionych badań lub też istotnie dłuższy czas trwania choroby w porównaniu z badaniem UKPDS. Istotnym elementem wydaje się również międzygrupowa różnica w wyrównaniu metabolicznym wyrażona wartością $\mathrm{HbA}_{1 \mathrm{c}}(0,67 \%$ w okresie 5 lat dla populacji badania ADVANCE vs. $2 \%$ w okresie 6,5 roku dla populacji badania DCCT czy też 0,9\% w okresie 10 lat dla populacji badania UKPDS). Warto podkreślić, że wyjściowe wartości $\mathrm{HbA}_{1 \mathrm{c}}$ były także różne w analizowanych badaniach (> 8,5\% w DCCT i UKPDS vs. 7,5\% w ADVANCE), co mogło wpływać na wyniki końcowe. Ponadto okres obserwacji w badaniu ADVANCE-ON był istotnie krótszy (5 lat vs. > 10 lat w DCCT i UKPDS), co może być okresem niewystarczającym do ujawnienia się korzyści naczyniowych.

Podsumowując, należy stwierdzić, że wyniki badania ADVANCE-ON potwierdziły generalnie wnioski płynące z większości wcześniejszych randomizowanych badań klinicznych i ich otwartych kontynuacji, dotyczące braku dowodów na korzyści wynikające z intensywnej terapii hipoglikemizującej w długotrwałej cukrzycy typu 2 na redukcję umieralności oraz zdarzeń o charakterze makroangiopatii. Pokazały ono natomiast zmniejszenie nerkowych punktów końcowych. Wyniki ramienia hipotensyjnego wskazują na potrzebę intensywnego leczenia hipotensyjnego, ponieważ skutkuje ono redukcją punktów końcowych o charakterze mikro- i makroangiopatii u pacjentów o opisanej charakterystyce.

\section{PIŚMIENNICTWO}

1. Standards of medical care in diabetes - 2015: summary of revisions. Diabetes Care 2015 Jan; 38 Suppl: S4. PubMed PMID: 25537706. Epub 2014/12/30.

2. Patel A.; ADVANCE Collaborative Group; MacMahon S., Chalmers J. i wsp. Effects of a fixed combination of perindopril and indapamide on macrovascular and microvascular outcomes in patients with type 2 diabetes mellitus (the ADVANCE trial): a randomised controlled trial. Lancet 2007; 370: 829-840.

3. Zoungas S., Chalmers J., Neal B. i wsp.; for the ADVANCE-ON Collaborative Group. follow-up of blood-pressure lowering and glucose control in type 2 diabetes. N. Engl. Med. 2014; 371: 1392-1406. 
4. Holman R.R., Paul S.K., Bethel M.A., Neil H.A., Matthews D.R. Long-term follow-up after tight control of blood pressure in type 2 diabetes. N. Engl. J. Med. 2008; 359: 1565-1576.

5. Holman R.R., Paul S.K., Bethel M.A., Matthews D.R., Neil H.A. 10-year follow-up of intensive glucose control in type 2 diabetes. N. Engl. J. Med. 2008; 359:1577-1589.

6. Adler A.I., Stratton I.M., Neil H.A. i wsp. Association of systolic blood pressure with macrovascular and microvascular complications of type 2 diabetes (UKPDS 36): prospective observational study. BMJ 2000; 321: 412-419.

7. Gerstein H.C., Miller M.E., Byington R.P. i wsp. Effects of intensive glucose lowering in type 2 diabetes. N. Engl. J. Med. 2008; 358: 2545-2559.

8. Duckworth W., Abraira C., Moritz T. i wsp. Glucose control and vascular complications in veterans with type 2 diabetes. $\mathrm{N}$. Engl. J. Med. 2009; 360: 129-139.

9. The Action to Control Cardiovascular Risk in Diabetes Study G. Effects of intensive glucose lowering in type 2 diabetes. N. Engl. J. Med. 2008; 358: 2545-2559.
10. Perkovic V., Heerspink H.L., Chalmers J. i wsp. Intensive glucose control improves kidney outcomes in patients with type 2 diabetes. Kidney Int. 2013; 83: 517-523.

11. Gaede P., Vedel P., Larsen N., Jensen G.V., Parving H.H., Pedersen O. Multifactorial intervention and cardiovascular disease in patients with type 2 diabetes. N. Engl. J. Med. 2003; 348: 383-393 .

12. Gaede P., Lund-Andersen H., Parving H.H., Pedersen O. Effect of a multifactorial intervention on mortality in type 2 diabetes. N. Engl. J. Med. 2008; 358: 580-591.

13. Bosch J., Lonn E., Pogue J., Arnold J.M., Dagenais G.R., Yusuf S.; HOPE/HOPETOO Study Investigators. Long-term effects of ramipril on cardiovascular events and on diabetes: results of the HOPE study extension. Circulation 2005; 112: 1339-1346.

14. Staessen J.A., Thijs L., Fagard R. i wsp.; Systolic Hypertension in Europe (Syst-Eur) Trial Investigators. Effects of immediate versus delayed antihypertensive therapy on outcome in the Systolic Hypertension in Europe Trial. J. Hypertens. 2004; 22: 847-857. 